\title{
Problematic Use of ICTs in Trainee Teachers during COVID-19: A Sex- Based Analysis
}

\author{
Ernesto Colomo Magaña \\ Department of Theory and History of Education, University of Malaga (UMA), Spain \\ ORCID: 0000-0002-3527-7937 \\ Andrea Cívico Ariza \\ Education Area, Valencian International University, Spain \\ ORCID: 0000-0003-3094-5841 \\ Julio Ruiz Palmero \\ Department of Didactics and School Organization, University of Malaga (UMA), Spain \\ ORCID: 0000-0002-6958-0926 \\ Enrique Sánchez Rivas \\ Department of Theory and History of Education, University of Malaga (UMA), Spain \\ ORCID: 0000-0003-2518-2026
}

Received: 22 Feb 2021

Accepted: 24 Apr 2021

\begin{abstract}
The excessive use of ICTs is a growing problem among young people. The social isolation caused by COVID19 can increase these inappropriate behaviour. This study aims at analysing the problematic use of ICTs in trainee teachers based on the gender variable before and after the COVID-19 lockdown based on the gender variable. A longitudinal panel design was carried out with pre-test and post-test measurements based on the gender variable. The sample consisted of 147 students from the Faculty of Education at the University of Malaga who were tested using a validated instrument: MULTICAGE-TIC. The results show that women used ICTs at a higher risk than men before lockdown, except for video games. During lockdown, men obtain higher scores than women in all the analysed ICTs (except for mobile phones). Both genders reach dependency level in all ICTs except for video games in women. The significant increase in all ICTs shows that the effects of the pandemic, such as restrictions on mobility and social interaction, have influenced such growth.
\end{abstract}

Keywords: addiction, ICT, educational personnel training, COVID-19

\section{INTRODUCTION}

The situation generated by the spread of COVID-19 has caused a health problem that has affected other areas too, such as politics, the economy, society, and education. When it was declared a pandemic, decisions had to be made regarding public health measures, which resulted in changes to the rest of everyday areas. In Spain, the state of emergency was declared in March 2020, followed by a lockdown in the months after the health emergency caused by COVID-19 (Real Decreto 463/2020), posing a challenge for the country's educational structure. 
The different lockdown phases and the restrictive measures taken meant an interruption of the usual faceto-face educational model, leading to the implementation of technology-supported remote training processes in which online education became widespread in the different stages of the education system (Cuevas et al., 2021; Dorsha, 2021). This has increased the number of hours that students use technological devices and spend in front of screens and on the Internet, adding educational time to their leisure time connected to the same resources and programmes. In this sense, the potential that resources and technologies have in the educational field (Sánchez-Rivas et al., 2017) does not mean that they are exempt from the risk of an inappropriate or abusive use. This study aims to delve into how the pandemic has affected university students in relation to a problematic use of ICTs.

It is worth mentioning that, before the pandemic, the Internet and technologies already enjoyed an unquestionable social relevance in Spain. The Spanish Institute of Statistics (2020) reveals that $95.4 \%$ of Spanish households have an internet connection and that there are more internet users (93.2\%) than computer users (81.4\%). This is mainly because the web can be accessed through different technological devices such as mobile phones, and in Spain $99.5 \%$ of Internet users connect to the broadband through their phones. Within this widespread practice, this study focuses on the use of Internet and how data were affected during the lockdown period caused by COVID-19.

Again, according to the information by the Spanish Institute of Statistics (2020), the most frequent activities during the pandemic among the adult population (16 to 74 years old) were the following: instant messaging services such as WhatsApp by $89.5 \%$ (it was $85.1 \%$ in 2019); information search on goods or services by $78.3 \%$ (surpassing the $72.9 \%$ in 2019); and video calls or phone calls using the Internet by $77.7 \%$ (as compared to $54.9 \%$ in 2019). As observed, there is an exponential increase in the use of the Internet and some services related to internet access during the pandemic, as instant messaging (4.4\% increase) or video calls $(22.8 \%$ increase). Hence, there is an interrelation of variables that influence the increase in connection time, namely: 1) online teaching, where educational processes are mediated by technologies (Flores-Cuevas, 2018); 2) physical, social isolation as a result of the lockdown imposed in Spain, which multiplied virtual interactions as a coping strategy (Matas-Terrón et al., 2020); 3) youth leisure itself, which involves monitoring, communication and interaction through different channels (García-Jiménez et al., 2018; González-Cortés, 2020; Viñals et al., 2014) or playing video games (Marín-Díaz et al., 2019; Martín del Pozo, 2015).

Given the relevance and increase in the use of ICTs, it is now necessary to address the disorders related to internet addiction, which youngsters of different age groups and cultural contexts had already been suffering from for years (De la Villa Moral \& Suárez, 2016; Hinojo-Lucena, 2020; Marín-Díaz, 2020; Pedrero-Pérez et al., 2018; Tsitsika et al., 2013).

Regarding the Internet, a number of studies show how dependency and excessive use affect psychological, biological and social aspects, thus having an impact on the reduction of physical activity, greater isolation or states of anxiety (Aznar-Díaz et al., 2019; Cho et al., 2014; Jasso Medrano et al., 2017; Saikia et al., 2019). This internet addiction is also reflected in the inappropriate use of technological devices to browse the Internet, along with applications to communicate and interact with other people and/or play online.

It is worth stressing the role played by smartphones to access the Internet, as well as the various applications. It should be noted that addiction is not generated by the need to use smartphones, but rather in relation to the different apps that can be used on the phone. As well as the excessive use of the Internet, there are also studies that endorse how an excessive use of mobile phones can lead to problems such as depression, anxiety or insomnia (Elhai et al., 2017; Miri et al., 2020; Ostovar et al., 2016; Ruiz-Palmero et al. 2016). Among the problematic uses of mobile phones associated with internet access, we find browsing through social networks the most frequent one, as they are used by $90.8 \%$ of people between 16 and 24 years old in Spain (Spanish Institute of Statistics, 2020).

Social network addiction can be considered a subtype of internet addiction (Błachnio et al., 2015; RuizPalmero et al., 2019), sharing many characteristics. Social network dependency is caused both to their possible use as a channel of interaction and communication among young people, as well as to the strategies 
promoted by social networks to condition emotional responses and trigger behaviours that generate the need to remain connected (Peng et al., 2019).

Finally, video games are yet another technological device where problematic uses have been detected. In Spain, according to the Spanish Association of Video Games, the number of players has reached 15 million, accounting for $42 \%$ of the population between 6 and 64 years old, with 6.7 hours of use per week (Spanish Association of Video Games, 2019). Addiction to video games will be recognised as a mental disorder by the World Health Organization in 2022 (WHO, 2019), despite studies such as that by Entwistle et al. (2020) stating that video games are not intrinsically addictive and that only a few players have a problem with them (Desai et al., 2010; Haagsman et al., 2012).

Such background shows the existence of a problem with technologies, which negatively impacted the increase in the use of technologies in disorders related to internet addiction during the pandemic (Dong et al., 2020; Paricio del Castillo \& Pando Velasco, 2020). Furthermore, it is worth mentioning the lack of resources and strategies for families to prevent such problematic use (Orte Socías et al., 2020).

Therefore, this study sets out to examine the problematic use of ICTs in trainee teachers based on the gender variable. Also, the study will check for significant gender-based differences before and during the COVID-19 lockdown. Thus, the study will be able to find out the impact of the pandemic in terms of an inappropriate use of technologies.

\section{MATERIAL AND METHODS}

\section{Methodological Approach}

This research study followed a quantitative, ex post facto and quasi-experimental design (non-randomly set groups) with a longitudinal panel design with pre-test and post-test measures. Data were collected through a questionnaire on the inappropriate and problematic use of ICTs in a group of pre-set subjects at two separate points in time. After collecting data from the participants at both times, descriptive and inferential analyses were carried out taking into account gender-based differences.

\section{Sample}

A non-probabilistic (for convenience) sampling was carried out on 147 undergraduates of the Faculty of Educational Sciences at the University of Malaga during the 2019/2020 academic year. Considering Otzen and Manterola (2017), the subjects who agreed to participate were included. Regarding their gender, $72.79 \%$ (107) were women and $27.71 \%$ (40) men. The average age of the participants was 20.52 , with a standard deviation of 1.77. As for their studies, $61.22 \%$ (90) were students of the Degree in Primary Education, $16.33 \%$ (24) in Early Childhood Education, 13.61\% (20) in Social Education and 8.84\% (13) in Pedagogy.

\section{Instrument}

To measure the use and abuse of ICTs, the MULTICAGE-TIC instrument was used (Pedrero-Pérez et al., 2018), using a variant of the MULTICAGE-CAD-4 (Pedrero-Pérez et al., 2007) to measure compulsive behaviours. The instrument consists of 20 items, distributed in 5 scales: internet, mobile phones, video games, instant messaging, and social networks. Each ICT-related scale includes four questions in relation to problem behaviours: A) estimation of excessive use of the device (time spent); B) estimation of excessive use of the device in other actors' opinion; C) difficulty to stop the behaviour; D) difficulty to voluntarily interrupt the behaviour. They are closed questions (yes/no questions), and the number of affirmative answers on each ICT scale is recorded to detect a problematic use of them. Interpretations regarding the number of affirmative answers are as follows: no problems ( 0 or 1 affirmative answer); problematic use ( 2 affirmative answers); abuse ( 3 affirmative answers); dependency ( 4 affirmative answers).

The instrument has appropriate psychometric properties and meets reliability and validity criteria. Regarding reliability, the scales of the instrument showed satisfactory levels, ranging between acceptable and excellent results: internet scale $(\alpha=0.80)$; mobile phone scale $(\alpha=0.72)$; video game scale $(\alpha=0.90)$; instant messaging 
scale $(\alpha=0.89)$; social network scale $(\alpha=0.93)$. Regarding validity, it meets content validity after being implemented in several research studies (Méndez-Gago \& González-Robledo, 2018; Pedrero-Pérez et al., 2018). Besides, the Confirmatory Factor Analysis (CFA) has a satisfactory fit in the 5 -scale structure with 4 questions each $(\mathrm{RMR}=0.012 ; \mathrm{GFI}=0.96 ; \mathrm{AGFI}=0.95 ; \mathrm{NFI}=0.94 ; \mathrm{RFI}=0.92 ; \mathrm{PGFI}=0.73 ; \mathrm{PNFI}=0.79)$.

\section{Procedure}

The present research study is motivated by an interest on problems related to the inappropriate use of ICTs. Given the exceptional situation derived from the COVID-19 pandemic, during which virtual interactions increased both personally and professionally, this study is set out to explore how the new normal affected trainee teachers in their use and abuse of ICTs. Due to the health crisis, the University of Malaga had to adapt all educational processes to the virtual context. Teaching at the Faculty of Educational Sciences went online from the second term of the 2019/2020 academic year. In relation to this situation and along with the national lockdown imposed in Spain, the study aims at answering whether the use and abuse of ICTs increased as a result of the isolation caused by the mandatory confinement. Data collection was carried out on a voluntary basis. Participating students who chose to take part in the sample responded to a MULTICAGETIC questionnaire at two points in time: at end of February 2020 (beginning of the new term), to learn about the students' problematic use of ICTs; and at end of April 2020, during the state of emergency declared in Spain and the resulting lockdown, to learn about the evolution in the use of ICTs. Answers were collected through a LimeSurvey questionnaire, chosen because it allows to restrict answers to potential participants and send them reminders. The questionnaire was submitted electronically.

\section{Data Analysis}

Starting from the set objectives, the corresponding statistical tests were applied. Firstly, an exploratory analysis of the descriptive statistics of pre-test and post-test answers was carried out, considering the total sample and the gender variable. Secondly, an inferential analysis was conducted regarding the existence of significant differences, analysing the problematic use of ICTs in two points of time: before lockdown (pretest) and after lockdown (post-test), both in the total sample as well as in relation to gender (nominal, dichotomous variable). With regards to parametric assumptions of the total sample (Table 1 ) in the pre-test and post-test, both the Leven statistic (less than 0.05 significance $(p \leq 0.05)$ in 4 out of the 5 scales) and the Kolmogorov-Smirnov test (less than 0.05 significance $(p \leq 0.05$ ) in all scales) did not achieve normality, which led to the application of non-parametric tests in subsequent inferential analyses. If we consider the parametric assumptions of the gender variable (Table 2 ) in the pre-test and post-test, the Leven statistic only shows a greater significance than $0.05(p \leq 0.05)$ in 2 out of the 5 scales in the pre-test, while the KolmogorovSmirnov test shows a lower significance than $0.05(p \leq 0.05)$ in all scales both in females and males. Results show that data do not achieve normality, thus resorting to non-parametric tests for the subsequent analysis of significant differences. The software used was SPSS v.25.

\section{RESULTS}

First, an exploratory analysis of the descriptive results of applying MULTICAGE-TIC on the sample was conducted, before and during lockdown, together with parametric assumptions of homoscedasticity and normality (Table 1).

As can be seen, the results highlight an increase in every scale between the pre-test and the post-test, thus increasing the means between 1.15 and 1.65 points. Data show that the lockdown resulting from the COVID19 pandemic had an impact on the problematic use of ICTs by increasing each scale by more than 1 point. It is worth emphasising the mobile phone as the most used device before $(2.37 \pm 0.91)$ and after $(3.88 \pm 0.38)$ the lockdown. The opposite took place with video games ( $0.46 \pm 0.87$ in the pre-test, $2.11 \pm 1.47$ in the posttest). 
Table 1. Pre-test and post-test descriptive statistics

\begin{tabular}{|c|c|c|c|c|c|c|c|}
\hline \multirow{2}{*}{ Scale } & \multirow{2}{*}{ Moment } & \multirow{2}{*}{$\mathrm{M} \pm \mathrm{SD}$} & \multicolumn{2}{|c|}{ Kolmogorov-Smirnov } & \multicolumn{2}{|c|}{ Levene } & \multirow{2}{*}{ Cohen's d } \\
\hline & & & $\mathrm{F}$ & p. & $\mathrm{F}$ & p. & \\
\hline \multirow[t]{2}{*}{ Internet } & Pre-test & $2.06 \pm 1.07$ & 0.171 & $0.000^{*}$ & \multirow{2}{*}{36.671} & \multirow{2}{*}{$0.000 *$} & \multirow{2}{*}{-1.89} \\
\hline & Post-test & $3.70 \pm 0.60$ & 0.453 & $0.000 *$ & & & \\
\hline \multirow[t]{2}{*}{ Mobile phone } & Pre-test & $2.37 \pm 0.91$ & 0.256 & $0.000 *$ & \multirow{2}{*}{123.170} & \multirow{2}{*}{$0.000^{*}$} & \multirow{2}{*}{-2.17} \\
\hline & Post-test & $3.88 \pm 0.38$ & 0.524 & $0.000 *$ & & & \\
\hline \multirow[t]{2}{*}{ Video games } & Pre-test & $0.46 \pm 0.87$ & 0.441 & $0.000 *$ & \multirow{2}{*}{62.527} & \multirow{2}{*}{$0.000^{*}$} & \multirow{2}{*}{-1.37} \\
\hline & Post-test & $2.11 \pm 1.47$ & 0.173 & $0.000 *$ & & & \\
\hline \multirow[t]{2}{*}{ Instant messaging } & Pre-test & $1.97 \pm 1.23$ & 0.167 & $0.000^{*}$ & \multirow{2}{*}{13.557} & \multirow{2}{*}{$0.000 *$} & \multirow{2}{*}{-1.40} \\
\hline & Post-test & $3.48 \pm 0.90$ & 0.417 & $0.000 *$ & & & \\
\hline \multirow[t]{2}{*}{ Social networks } & Pre-test & $2.12 \pm 1.24$ & 0.163 & $0.000 *$ & \multirow{2}{*}{0.659} & \multirow{2}{*}{0.418} & \multirow{2}{*}{-0.98} \\
\hline & Post-test & $3.27 \pm 1.11$ & 0.385 & $0.000 *$ & & & \\
\hline
\end{tabular}

$*=p<0.05$

Table 2. Pre-test and post-test descriptive statistics according to the gender variable

\begin{tabular}{|c|c|c|c|c|c|c|c|c|c|}
\hline \multirow{3}{*}{ Scale } & \multirow{3}{*}{ Moment } & \multicolumn{3}{|c|}{ Women } & \multicolumn{3}{|c|}{ Men } & \multirow{2}{*}{\multicolumn{2}{|c|}{ Levene }} \\
\hline & & \multirow{2}{*}{$\mathrm{M} \pm \mathrm{SD}$} & \multicolumn{2}{|c|}{ Kolmogorov-Smirnov } & \multirow{2}{*}{$\mathrm{M} \pm \mathrm{SD}$} & \multicolumn{2}{|c|}{ Kolmogorov-Smirnov } & & \\
\hline & & & $\mathrm{KS}$ & p. & & $\mathrm{F}$ & p. & $\mathrm{F}$ & p. \\
\hline \multirow[t]{2}{*}{ Internet } & Pre-test & $2.21 \pm 1.07$ & 0.184 & 0.000 & $1.68 \pm 1.00$ & 0.201 & 0.000 & 0.007 & 0.934 \\
\hline & Post-test & $3.64 \pm 0.62$ & 0.427 & 0.000 & $3.85 \pm 0.53$ & 0.511 & 0.000 & 10.820 & 0.001 \\
\hline \multirow[t]{2}{*}{ Mobile phone } & Pre-test & $2.49 \pm 0.93$ & 0.252 & 0.000 & $2.05 \pm 0.78$ & 0.250 & 0.000 & 4.916 & 0.028 \\
\hline & Post-test & $3.93 \pm 0.26$ & 0.537 & 0.000 & $3.78 \pm 0.58$ & 0.502 & 0.000 & 20.170 & 0.000 \\
\hline \multirow[t]{2}{*}{ Video games } & Pre-test & $0.33 \pm 0.82$ & 0.487 & 0.000 & $0.80 \pm 0.91$ & 0.310 & 0.000 & 5.922 & 0.016 \\
\hline & Post-test & $1.63 \pm 1.36$ & 0.210 & 0.000 & $3.40 \pm 0.84$ & 0.387 & 0.000 & 13.602 & 0.000 \\
\hline \multirow{2}{*}{$\begin{array}{l}\text { Instant } \\
\text { messaging }\end{array}$} & Pre-test & $2.13 \pm 1.24$ & 0.198 & 0.000 & $1.53 \pm 1.11$ & 0.241 & 0.000 & $0 . .698$ & $0 . .405$ \\
\hline & Post-test & $3.40 \pm 0.84$ & 0.389 & 0.000 & $3.70 \pm 0.85$ & 0.487 & 0.000 & 6.863 & 0.010 \\
\hline \multirow{2}{*}{ Social networks } & Pre-test & $2.25 \pm 1.13$ & 0.178 & 0.000 & $1.75 \pm 1.45$ & 0.187 & 0.000 & 4.262 & 0.041 \\
\hline & Post-test & $3.17 \pm 1.14$ & 0.357 & 0.000 & $3.53 \pm 1.01$ & 0.456 & 0.000 & 4.747 & 0.031 \\
\hline
\end{tabular}

$*=p<0.05$

Next, gender-based descriptive results and parametric assumptions are shown in Table 2.

Both genders show a considerable increase in the use of ICTs in relation to before and during lockdown. In the case of women, the increase ranges from 0.92 to 1.44 points. The mobile phone was the most used ICT before (2.49 \pm 0.93$)$ and during lockdown $(3.93 \pm 0.26)$, going from risk behaviour to dependency; while video games were the least used $(0.33 \pm 0.82$ in the pre-test and $1.63 \pm 1.36$ in the post-test), going from nonproblematic behaviour to risky use. In the case of men, the increase ranges from 1.73 to 2.60 points, which explains the shift from non-problematic use before lockdown (except for mobiles, that was risky), to dependency after lockdown in all ICTs. Mobile phones obtained the highest score in males before lockdown $(2.05 \pm 0.78$, risky use), and the Internet took its place during lockdown $(3.85 \pm 0.53$, dependent use). Video games obtained the lowest score before and during lockdown in males $(0.80 \pm 0.91$ in the pre-test, $3.40 \pm 0.84$ in the post-test), although there is a drastic shift in their use, going from non-problematic use to dependency during lockdown.

After observing these results, the next step was to address the scores from the pre-test and the post-test according to the gender variable, in order to check for gender-based significant differences in the problematic use of ICTs before and during confinement. First, the pre-test results. Results show that women score higher than men on all scales before lockdown, except for video games. Women make a risky use of the Internet (2.21), instant messaging (2.13) and social networks (2.25), approaching abuse on mobile phones (2.49), while the use of video games is not problematic (0.33). On the contrary, men make a non-problematic use of all ICTs, except for mobile phones (2.05), where their use is considered risky.

As for significant differences, the non-parametric Mann-Whitney $U$ test was applied to compare the medians of the scales in the pre-test (Table 3 ). 
Table 3. Gender-based significant differences in the pre-test

\begin{tabular}{|c|c|c|c|c|c|}
\hline Scale & Gender & $\mathrm{N}$ & $\mathrm{M} \pm \mathrm{SD}$ & p. & $r$ \\
\hline \multirow[t]{2}{*}{ Internet } & Women & 107 & $2.21 \pm 1.07$ & \multirow{2}{*}{$0.011^{*}$} & \multirow{2}{*}{-0.21} \\
\hline & Men & 40 & $1.68 \pm 1.00$ & & \\
\hline \multirow[t]{2}{*}{ Mobile phone } & Women & 107 & $2.49 \pm 0.93$ & \multirow{2}{*}{$0.009 *$} & \multirow{2}{*}{-0.22} \\
\hline & Men & 40 & $2.05 \pm 0.78$ & & \\
\hline \multirow[t]{2}{*}{ Video games } & Women & 107 & $0.33 \pm 0.82$ & \multirow{2}{*}{$0.000 *$} & \multirow{2}{*}{-0.32} \\
\hline & Men & 40 & $0.80 \pm 0.91$ & & \\
\hline \multirow[t]{2}{*}{ Instant messaging } & Women & 107 & $2.13 \pm 1.24$ & \multirow{2}{*}{$0.009 *$} & \multirow{2}{*}{-0.22} \\
\hline & Men & 40 & $1.53 \pm 1.11$ & & \\
\hline \multirow[t]{2}{*}{ Social networks } & Women & 107 & $2.25 \pm 1.13$ & \multirow{2}{*}{$0.047^{*}$} & \multirow{2}{*}{-0.16} \\
\hline & Men & 40 & $1.75 \pm 1.45$ & & \\
\hline
\end{tabular}

$*=p<0.05$

Table 4. Gender-based significant differences in the post-test

\begin{tabular}{|c|c|c|c|c|c|}
\hline Scale & Gender & $\mathrm{N}$ & $\mathrm{M} \pm \mathrm{SD}$ & p. & $r$ \\
\hline \multirow[t]{2}{*}{ Internet } & Women & 107 & $3.64 \pm 0.62$ & \multirow{2}{*}{$0.019 *$} & \multirow{2}{*}{-0.19} \\
\hline & Men & 40 & $3.85 \pm 0.53$ & & \\
\hline \multirow[t]{2}{*}{ Mobile phone } & Women & 107 & $3.93 \pm 0.26$ & \multirow{2}{*}{0.139} & \multirow{2}{*}{-0.12} \\
\hline & Men & 40 & $3.78 \pm 0.58$ & & \\
\hline \multirow[t]{2}{*}{ Video games } & Women & 107 & $1.63 \pm 1.36$ & \multirow{2}{*}{$0.000 *$} & \multirow{2}{*}{-0.54} \\
\hline & Men & 40 & $3.40 \pm 0.84$ & & \\
\hline \multirow[t]{2}{*}{ Instant messaging } & Women & 107 & $3.40 \pm 0.84$ & \multirow{2}{*}{$0.021 *$} & \multirow{2}{*}{-0.19} \\
\hline & Men & 40 & $3.70 \pm 0.85$ & & \\
\hline \multirow[t]{2}{*}{ Social networks } & Women & 107 & $3.17 \pm 1.14$ & \multirow{2}{*}{$0.046 *$} & \multirow{2}{*}{-0.16} \\
\hline & Men & 40 & $3.53 \pm 1.01$ & & \\
\hline
\end{tabular}

$*=p<0.05$

Results have proven the existence of significant differences in all scales before lockdown, with women's scores being always higher except in the case of video games. Nevertheless, the effect size was small in all scales.

Next are the results from the post-test. During lockdown, men scored higher than women on all scales except for mobile phone use. Both men and women make an abusive or dependent use of the Internet, mobile phones, instant messaging, and social networks. In the case of video games, women are at the beginning of risky behaviour (1.63), while men use them abusively (3.40).

In order to check for significant differences in the post-test, the non-parametric Mann-Whitney $U$ test was conducted (Table 4).

Significant differences are shown in the use of the Internet (effect size low), video games (effect size medium), instant messaging (effect size low), and social networks (effect size low) during lockdown, where men scored higher than women on all scales.

Finally, the study addresses the evolution of gender-based results of the total sample both before and during lockdown (Figure 1).

The graph shows a considerable increase in all ICTs for both genders. Before lockdown, some technologies already reported a use that was close to being abuse, such as mobile phones in women, although the usual behaviour was risky usage (except for video games in both genders), which could only pose potential danger in the event of new aspects emerging and influencing their increased use. This situation took place after the COVID-19 pandemic was declared, leading to isolation and confinement in Spain, which resulted in an increase in virtual interactions, both at a personal and professional level, with the corresponding increased use of ICTs. Thus, during lockdown, an already problematic use of ICTs translated into dependency in both genders, except for video games in women, which remains at risky use level. As shown by the graph, we are 


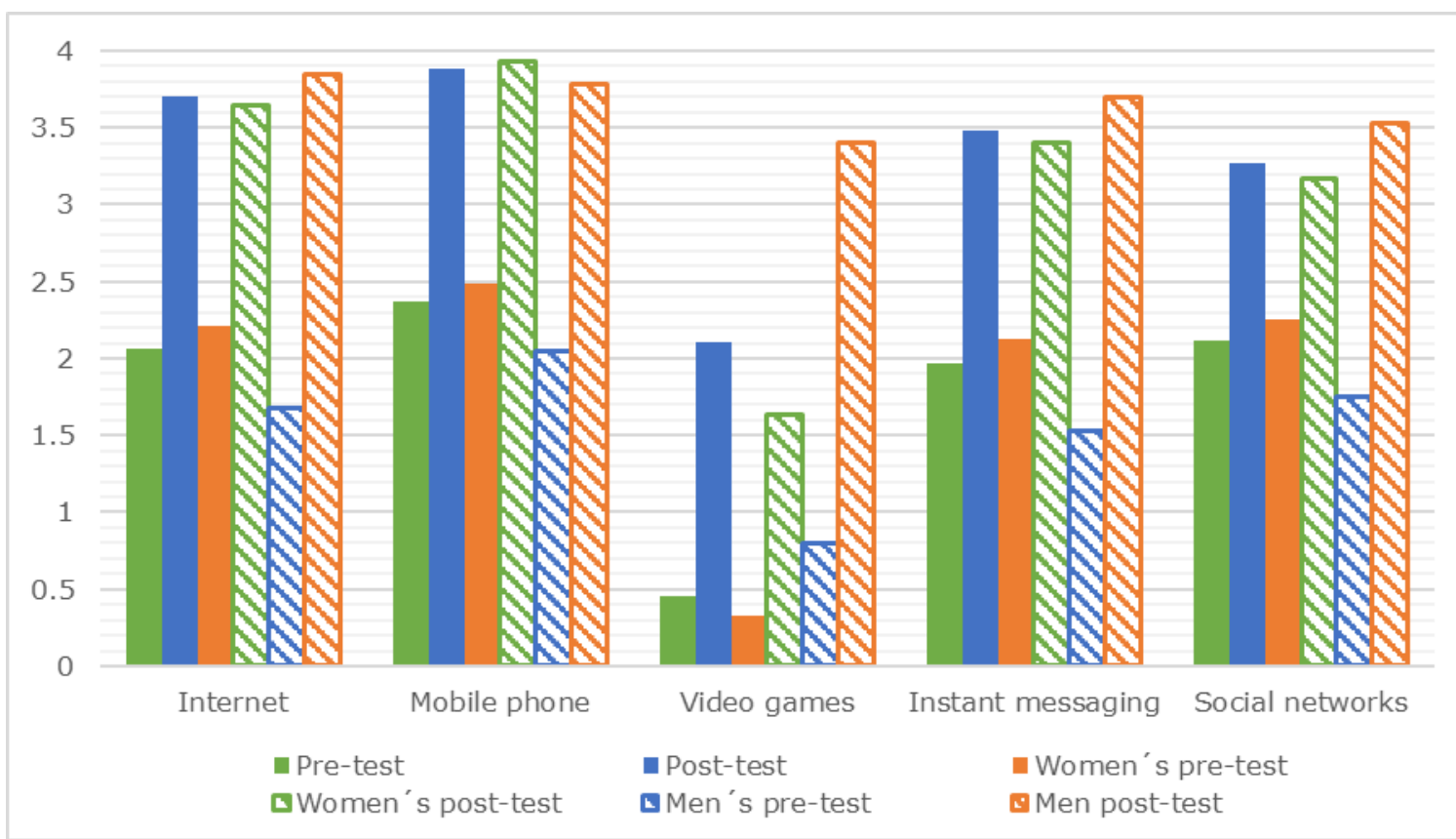

Figure 1. Pre-test/post-test comparison by scales

Table 5. Significant differences in scales depending on the moment and gender

\begin{tabular}{lcccccc}
\hline \multirow{2}{*}{ Scale } & \multicolumn{3}{c}{ Gender } & \multicolumn{3}{c}{ Moment } \\
\cline { 2 - 7 } & $\mathrm{F}$ & $\mathrm{p}$. & $\eta^{2}$ & $\mathrm{~F}$ & $\mathrm{p}$. & $\eta^{2}$ \\
\hline Internet & 2.042 & 0.154 & 0.007 & 261.624 & $0.000^{*}$ & 0.473 \\
Mobile phone & 10.689 & $0.001^{*}$ & 0.035 & 361.406 & $0.000^{*}$ & 0.554 \\
Video games & 60.538 & $0.000^{*}$ & 0.172 & 165.460 & $0.000^{*}$ & 0.362 \\
Instant messaging & 1.186 & 0.277 & 0.004 & 145.557 & $0.000^{*}$ & 0.333 \\
Social networks & 0.223 & 0.637 & 0.001 & 70.082 & $0.000^{*}$ & 0.194 \\
\hline
\end{tabular}

$*=p<0.05$

Table 6. Gender-based significant differences depending on the moment (pre-test/post-test)

\begin{tabular}{|c|c|c|c|c|c|c|c|c|c|c|}
\hline \multirow{3}{*}{ Scale } & \multirow{3}{*}{ Moment } & \multicolumn{3}{|c|}{ Women } & \multicolumn{3}{|c|}{ Men } & \multicolumn{3}{|c|}{ Total } \\
\hline & & \multirow{2}{*}{$\mathrm{M} \pm \mathrm{SD}$} & \multicolumn{2}{|c|}{ Wilcoxon } & \multirow{2}{*}{$\mathrm{M} \pm \mathrm{SD}$} & \multicolumn{2}{|c|}{ Wilcoxon } & \multirow{2}{*}{$\mathrm{M} \pm \mathrm{SD}$} & \multicolumn{2}{|c|}{ Wilcoxon } \\
\hline & & & $Z$ & $p$ & & $Z$ & $p$ & & $Z$ & $p$ \\
\hline \multirow{2}{*}{ Internet } & Pre-test & $2.21 \pm 1.07$ & \multirow{2}{*}{-8.329} & \multirow{2}{*}{$0.000^{*}$} & $1.68 \pm 1.00$ & \multirow{2}{*}{-5.572} & \multirow{2}{*}{$0.000 *$} & $2.06 \pm 1.07$ & \multirow{2}{*}{-9.987} & \multirow{2}{*}{$0.000 *$} \\
\hline & Post-test & $3.64 \pm 0.62$ & & & $3.85 \pm 0.53$ & & & $3.70 \pm 0.60$ & & \\
\hline \multirow{2}{*}{$\begin{array}{l}\text { Mobile } \\
\text { phone }\end{array}$} & Pre-test & $2.49 \pm 0.93$ & \multirow{2}{*}{-8.383} & \multirow{2}{*}{$0.000 *$} & $2.05 \pm 0.78$ & \multirow{2}{*}{-5.361} & \multirow{2}{*}{$0.000 *$} & $2.37 \pm 0.91$ & \multirow{2}{*}{-9.927} & \multirow{2}{*}{$0.000 *$} \\
\hline & Post-test & $3.93 \pm 0.26$ & & & $3.78 \pm 0.58$ & & & $3.88 \pm 0.38$ & & \\
\hline \multirow{2}{*}{ Video games } & Pre-test & $0.33 \pm 0.82$ & \multirow{2}{*}{-7.602} & \multirow{2}{*}{$0.000 *$} & $0.80 \pm 0.91$ & \multirow{2}{*}{-5.528} & \multirow{2}{*}{$0.000 *$} & $0.46 \pm 0.87$ & \multirow{2}{*}{-9.359} & \multirow{2}{*}{$0.000^{*}$} \\
\hline & Post-test & $1.63 \pm 1.36$ & & & $3.40 \pm 0.84$ & & & $2.11 \pm 1.47$ & & \\
\hline \multirow{2}{*}{$\begin{array}{l}\text { Instant } \\
\text { messaging }\end{array}$} & Pre-test & $2.13 \pm 1.24$ & \multirow{2}{*}{-7.621} & \multirow{2}{*}{$0.000 *$} & $1.53 \pm 1.11$ & \multirow{2}{*}{-5.377} & \multirow{2}{*}{$0.000 *$} & $1.97 \pm 1.23$ & -9327 & \\
\hline & Post-test & $3.40 \pm 0.84$ & & & $3.70 \pm 0.85$ & & & $3.48 \pm 0.90$ & -9.322 & 0.000 \\
\hline Social & Pre-test & $2.25 \pm 1.13$ & -5862 & $0000 *$ & $1.75 \pm 1.45$ & -4.934 & $0.000 *$ & $2.12 \pm 1.24$ & & \\
\hline networks & Post-test & $3.17 \pm 1.14$ & & & $3.53 \pm 1.01$ & & & $3.27 \pm 1.11$ & & \\
\hline
\end{tabular}

$*=p<0.05$

currently facing a real problem regarding the inappropriate use of technologies, which, at present is leading to dependent and abusive behaviours.

After this general exploratory analysis, the study is set out to check whether the observed differences are statistically significant. To do so, two tests are performed: ancova of various factors, to analyze the influence of the variables moment and gender on the scales (Table 5); and a non-parametric Wilcoxon $\mathrm{W}$ test is conducted to compare pre-test and post-test scores of the total sample and according to gender, in order to see how confinement affected the problematic use of ICTs for each gender and in all participants (Table 6). 
The data indicate that the moment variable has a significant influence on all scales, explaining between $19.4 \%$ and $55.4 \%$. However, the gender variable is only significant in the problematic use of mobile phones and video games, explaining $3.5 \%$ and $17.2 \%$ respectively.

Next, the scores are analyzed according to the moment according to gender and the total sample.

The data confirm the existence of significant differences between the pre-test and the post-test scores in all scales. Therefore, both women and men have increased their use of ICTs during lockdown (the same as the total sample of participants). It has therefore been proven that trainee teachers of both genders show an increase in problematic behaviours regarding the use of ICTs due to the confinement triggered by the effects of the COVID-19 pandemic in Spain.

\section{DISCUSSION}

This study aimed to analyse how the use of ICTs in trainee teachers of both genders has been affected by the health crisis caused by the COVID-19 pandemic. When focusing on the situation before the pandemic, results show patterns of non-problematic use of ICTs in general terms. However, as a result of the pandemic and the restrictions on mobility and social contact, the university population that makes up the sample has considerably increased their use of ICTs, reaching addiction patterns in most cases. Authors such as Dong et al. (2020), Lemenager et al. (2021) or Siste et al. (2020) also identified an increase in the use of ICTs linked to the pandemic, without concluding whether this increase is associated with a greater risk of addiction. In this study, the data showed that women had a more problematic use of ICTs than men before the pandemic, a situation that was reversed as a result of the confinement, as men had a more dependent use of technologies than women in the sample. Next, the main findings in each of the elements of analysis will be discussed.

Internet use was risky for women before the pandemic, while it was not problematic for men, with significant differences between the two. This confirms the findings of a number of studies stating that women are likely to show more addiction symptoms (Cimadevilla, \& Jenaro, 2019; López, 2018; Peris et al., 2020) and contradicts the research study by Fernández et al. (2020), where no significant gender-based differences were found in a sample of young Spaniards in relation to Internet addiction. During the pandemic, genderbased results were reversed, as men scored higher than women, with significant differences despite the fact that they were both making a dependent use of the Internet.

Based on the fact that mobile phones are the most used device by trainee teachers, the data showed that, both before and after lockdown, women make a more problematic use of mobile phones than men, which translated into abuse before lockdown and dependency during lockdown due to the isolation caused by the pandemic. These results are in line with several studies (Ballester et al., 2020; Chóliz et al., 2016; Ivanova et al., 2020; Long et al., 2016; Marín-Díaz et al., 2020), where women always display more addiction or an excessive use of mobile phones as compared to men.

The problematic use of smartphones and the Internet is closely related to the monitoring of social networks (Rosales \& Jasso Medrano, 2019), as these account for the most common channels of communication and interaction among young people. In terms of the effects of COVID-19 on social network use, before the lockdown women showed a more problematic use of social networks than men, in line with different studies (Gómez et al., 2017; Malo-Cerrato et al., 2018; Peris et al., 2018). However, this situation reversed during the lockdown, when men showed a greater dependency on social network, in line with the study by AparicioMartínez et al. (2020).

Regarding video games, men scored higher than women at both points in time analysed. While the use of video games was not risky for both genders before the pandemic, it turned into dependency in males and close to risky use in females. These results are in line with some studies showing that men are more attracted to video games than women (Desai et al., 2010; García-Olivas \& Piqueras, 2016), due to the fact that male adolescents seem to be more vulnerable to developing problematic gambling habits (Bilić \& Golub, 2011; Haagsman et al., 2012; Marín-Díaz et al., 2019). 


\section{CONCLUSION}

In short, social isolation and the restrictions derived from the confinement have caused a substantial increase in the use of technologies in both genders, with differences between them. This fact indicates that the social isolation generated by the restrictions caused by the pandemic has influenced the level of technology consumption, reflecting addictive behaviors. At an educational level, in the university context, the replacement of face-to-face classes with virtual or online models is a direct consequence of the increased use of these technologies. In this sense, to reduce the time of use related to university studies, it is recommended to adopt disconnection measures in the university context (shorter duration of classes in the virtual format, or reduce the sending of announcements, emails or work after hours of class). The aim is that the use of technologies is educational and has a pedagogical sense, with ICT being a tool for learning.

Among the limitations of this study, it is worth mentioning the size of the sample. It would be interesting to examine how the pandemic has influenced the use of ICTs in a larger sample of trainee teachers. In addition, interviews would be conducted to learn more about the purpose for which they use the different technologies, together with how long they consider that their use is excessive. The reason is that there may be students who reflect patterns of problematic use because their assessment is very restrictive, while others may have serious addiction problems, but understand the time they dedicate as adequate. Said interviews will be carried out with both university students and their families, to find out the different points of view and opinions on these aspects.

As future lines of research, further research is needed on how the use of ICTs evolves when the health crisis is over and we go back to a reality that is similar to the one we lived in before COVID-19. Also, it would be interesting for researchers who work on technology addiction to include other study variables and analyze the existence of correlations. Investigating social skills, sedentary lifestyle or academic results linked to technology addiction can give us information on how this problematic use affects other spheres of people. The objective is to develop interventions that help to overcome this problem and improve the aspects with which it is related.

Author contributions: All authors were involved in concept, design, collection of data, interpretation, writing, and critically revising the article. All authors approve final version of the article.

Funding: The authors received no financial support for the research and/or authorship of this article.

Declaration of interest: Authors declare no competing interest.

Data availability: Data generated or analysed during this study are available from the authors on request.

\section{REFERENCES}

Aparicio-Martínez, P., Ruiz-Rubio, M., Perea-Moreno, A.-J., Martínez-Jiménez, M. P., Pagliari, C., RedelMacías, M. D., \& Vaquero-Abellán, M. (2020). Gender differences in the addiction to social networks in the Southern Spanish university students. Telematics and Informatics, 46, 101304. https://doi.org/101304. 10.1016/j.tele.2019.101304

Aznar-Díaz, I., Kopecky, K., Romero, J. M., Cáceres, M. P., \& Trujillo-Torres, J. M. (2019). Patologías asociadas al uso problemático de Internet. Una revisión sistemática y meta-análisis en WOS y Scopus [Pathologies associated with problematic use of the Internet. A systematic review and meta-analysis on WOS and Scopus]. Investigación bibliotecológica, 34(82), https://doi.org/10.22201/iibi.24488321xe.2020.82.58118

229-253.

Ballester, M. L., Simó, C., Chover, E., Saus, C., Casal, C., \& Martínez, A. (2020). Self-Perception of Dependence as an Indicator of Smartphone Addiction-Establishment of a Cutoff Point in the SPAI-Spain Inventory. International Journal of Environmental Research and Public Health, 17(11), e3838. https://doi.org/10.3390/ijerph17113838

Bilić, V., \& Golub, T.L. (2011). Pathological videogame use: The role of gender, self-esteem and educational context. Hrvatska Revija Za Rehabilitacijska Istrazivanja, 47(2), 1-13. 
Błachnio, A., Przepiórka, A., \& Pantic, I. (2015). Internet use, Facebook intrusion, and depression: Results of a cross-sectional study. European Psychiatry, 30(6), 681-684. https://doi.org/10.1016/j.eurpsy.2015.04.002

Cho, H., Kwon, M., Choi, J.-H., Lee, S.-K., Choi, J. S., Choi, S.-W., \& Kim, D.-J. (2014). Development of the Internet addiction scale based on the Internet gaming disorder criteria suggested in DSM-5. Addictive Behaviors, 39(9), 1361-1366. https://doi.org/10.1016/j.addbeh.2014.01.020

Chóliz, M., Pinto, L., Phansalkar, S., Corr, E., Mujjahid, A., Flores, C., \& Barrientos, P. (2016). Development of a brief multicultural version of the Test of Mobile Phone Dependence (TMDbrief) questionnaire. Frontiers in Psychology, 7, 650. https://doi.org/10.3389/fpsyg.2016.00650

Cimadevilla, R., \& Jenaro, C. (2019). Impact on psychological health of internet and mobile phone abuse in a spanish sample of secondary students. Revista Argentina de Clínica Psicológica, 28(4), 339-347. https://doi.org/10.24205/03276716.2019.1147

Cuevas, N., Gabarda, V., Cívico, A., \& Colomo, E. (2021). Flipped classroom in COVID-19 times: a cross-talking perspective. International Journal of Educational research and Innovation (IJERI), (15), 326-341. https://doi.org/10.46661/ijeri.5439

De la Villa Moral, M., \& Suárez, C. (2016). Factores de riesgo en el uso problemático de Internet y del teléfono móvil en adolescentes españoles [Risk factors in problematic Internet and mobile phone use in Spanish adolescents]. Revista Iberoamericana de Psicología y Salud, 7(2), 69-78. https://doi.org/10.1016/j.rips.2016.03.001

Desai, R. A., Krishnan-Sarin, S., Cavallo, D., \& Potenza, M. N. (2010). Video-gaming among high school students: Health correlates, gender differences, and problematic gaming. Pediatrics, 126(6) e1414e1424. https://doi.org/10.1542/peds.2009-2706

Dong, H., Yang, F., Lu, X., \& Hao, W. (2020). Internet addiction and related psychological factors among children and adolescents in China during the Coronavirus Disease 2019 (COVID-19) epidemic. Frontiers in Psychiatry, 11, 751. https://doi.org/10.3389/fpsyt.2020.00751

Dorsah, P. (2021). Pre-service teachers' readiness for emergency remote learning in the wake of COVID-19. European Journal of STEM Education, 6(1), 01. https://doi.org/10.20897/ejsteme/9557

Elhai, J. D., Dvorak, R. D., Levine, J. C., \& Hall, B. J. (2017). Problematic smartphone use: A conceptual overview and systematic review of relations. Journal of Affective Disorders, 207, 251-259. https://doi.org/10.1016/j.jad.2016.08.030

Entwistle, G. J. M., Blaszczynski, A., \& Gainsbury, S. M. (2020). Are video games intrinsically addictive? An international online survey. Computers in Human Behavior, 112, 106464. https://doi.org/10.1016/j.chb.2020.106464

Fernández, S., Belzunegui, Á., Pastor, I., \& Valls, F. (2020). Compulsive Internet and Prevalence Substance Use among Spanish Adolescents. International Journal of Environmental Research and Public Health, 17(23), e8747. https://doi.org/10.3390/ijerph17238747

Flores-Cuevas, F. (2018). La formación pedagógica y el uso de las tecnologías de la información y comunicación dentro del proceso enseñanza aprendizaje como una propuesta para mejorar su actividad docente [Pedagogical training and the use of information and communication technologies within the teaching-learning process as a proposal to improve their teaching activity]. EDMETIC, 7(1), 151-173. https://doi.org/10.21071/edmetic.v7i1.10025

García-Jiménez, A., Tur-Viñes, V., \& Pastor Ruiz, Y. (2018). Consumo mediático de adolescentes y jóvenes [Media consumption of adolescents and young people]. Icono 14, 16(1), 22-46. https://doi.org/10.7195/ri14.v16i1.1101 
García-Oliva, C., \& Piqueras, J.A. (2016). Experiential avoidance and technological addictions in adolescents. Journal of Behavioral Addictions, 5(2), 293-303. https://doi.org/10.1556/2006.5.2016.041

Gómez, P., Rial, A., Braña, T., Golpe, S., \& Varela, J. (2017). Screening of problematic internet use among Spanish adolescents: prevalence and related variables. Cyberpsychology, Behavior, and Social Networking, 20(4), 259-267. https://doi.org/10.1089/cyber.2016.0262

González-Cortés, E., Córdoba-Cabús, A., \& Gómez, M. (2020). Una semana sin smartphone: usos, abuso y dependencia del teléfono móvil en jóvenes. Bordón. Revista De Pedagogía, 72(3), 105-121. https://doi.org/10.13042/Bordon.2020.79296

Jasso Medrano, J. L., López Rosales, F., \& Díaz Loving, R. (2017). Conducta adictiva a las redes sociales y su relación con el uso problemático del móvil. Acta de Investigación Psicológica, 7(3), 2832-2838. https://doi.org/10.1016/j.aipprr.2017.11.001

Haagsman, M. C., Pietersey, M. E., \& Peters, O. (2012). The Prevalence of Problematic Video Gamers in The Netherlands. Cyberpsychology, Behavior, and Social Networking, 15(3), 162-168. https://doi.org/10.1089/cyber.2011.0248

Hinojo-Lucena, F. J., Aznar-Díaz, I., Cáceres, M. P., Trujillo-Torres, J. M., \& Romero-Rodríguez, J.M. (2020). Sharenting: adicción a Internet, autocontrol y potos online de menores de edad [Sharenting: Internet addiction, self-control and online potos of minors]. Comunicar, 64, 97-108. https://doi.org/10.3916/C64-2020-09

Ivanova, A., Gorbaniuk, O., Błachnio, A., Przepiórka, A., Mraka, N., Polishchuk, V., \& Gorbaniuk, J. (2020). Mobile phone addiction, phubbing, and depression among men and women: A moderated mediation analysis. Psychiatric Quarterly, 91, 655-668. https://doi.org/10.1007/s11126-020-09723-8

Lemenager, T., Neissner, M., Koopmann, A., Reinhard, I., Georgiadou, E., Müller, A., Kiefer, F., \& Hillemacher, T. (2021). Covid-19 lockdown restrictions and online media consumption in Germany. International Journal of Environmental Research and Public Health, 18(1), e14. https://doi.org/10.3390/ijerph18010014

Long, J., Liu, T.Q., Liao, Y.H., Qi, C., He, H.Y., Chen, S.B., \& Billieux, J. (2016). Prevalence and correlates of problematic smartphone use in a large random sample of Chinese undergraduates. BMC Psychiatry, 16, e408. https://doi.org/10.1186/s12888-016-1083-3

López, O. (2018). Generalised Versus Specific Internet Use-Related Addiction Problems: A Mixed Methods Study on Internet, Gaming, and Social Networking Behaviours. International Journal of Environmental Research and Public Health, 15(12), e2913. https://doi.org/10.3390/ijerph15122913

Malo-Cerrato, S., Martín-Perpiñá, M.-M., Viñas-Poch, F. (2018). Excessive use of social networks: psychosocial profile of Spanish adolescents. Comunicar, 26, 101-110. https://doi.org/10.3916/C56-2018-10

Marín-Díaz, V., Morales-Díaz, M., \& Reche-Urbano, E. (2019). Educational possibilities of video games in the primary education stage according to teachers in training. A Case Study. NAER, Journal of New Approaches in Educational Research, 8(1), 42-49. https://doi.org/10.7821/naer.2019.1.330

Marín-Díaz, V., Muñoz-Gonzalez, J. M., \& Sampedro-Requena, B. S. (2020). Problematic relationships with smartphones of Spanish and Colombian university students. International Journal of Environmental Research and Public Health, 17(15), e5370. https://doi.org/10.3390/ijerph17155370

Martín Del Pozo, M. (2015). Videojuegos y aprendizaje colaborativo. Experiencias en torno a la etapa de Educación Primaria. Education in the Knowledge Society (EKS), 16(2), 69-89. https://doi.org/10.14201/eks20151626989 
Matas-Terrón, A., Sánchez-Barroso, C., \& Ríos-Ariza, J. M. (2020). How covid-19 lockdown time was predicted: implications of "collective intelligence" in educational research. IJERI: International Journal of Educational Research and Innovation, (15), 101-113. https://doi.org/10.46661/ijeri.4903

Méndez-Gago, S., \& González-Robledo, L. (2018). Uso y abuso de las tecnologías de la información y la comunicación por adolescentes. Un estudio representativo de la ciudad de Madrid [Use and abuse of information and communication technologies by adolescents. A representative study of the city of Madrid]. Universidad Camilo José Cela.

Miri, M., Tiyuri, A., Bahlgerdi, M., Miri, M., Miri, F., \& Salehiniya, H. (2020). Mobile addiction and its relationship with quality of life in medical students. Clinical Epidemiology and Global Health, 8(1), 229232. https://doi.org/10.1016/j.cegh.2019.08.004

Orte Socías, C., Ballester Brage, L., \& Nevot-Caldentey, L. (2020). Family support against COVID-19. https://doi.org/10.1590/SciELOPreprints.297

Ostovar, S., Allahyar, N., Aminpoor, H., Moafian, F., Nor, M. B. M., \& Griffiths, M. D. (2016). Internet addiction and its psychosocial risks (depression, anxiety, stress and loneliness) among Iranian adolescents and young adults: A structural equation model in a cross-sectional study. International Journal of Mental Health and Addiction, 14(3), 257-267. https://doi.org/10.1007/s11469-015-9628-0

Otzen, T., \& Manterola, C. (2017). Técnicas de muestreo sobre una población a estudio. [Sampling techniques on a study population] International Journal of Morphology, 35(1), 227-232. https://doi.org/10.4067/S0717-95022017000100037

Paricio del Castillo, R., \& Pando Velasco, M. F. (2020). Salud mental infanto-juvenil y pandemia de Covid-19 en España: Cuestiones y retos [Child and adolescent mental health and the Covid-19 pandemic in Spain: Issues and challenges]. Revista de Psiquiatría Infanto-Juvenil, 37(2), 30-44. https://doi.org/10.31766/revpsij.v37n2a4

Pedrero-Pérez, E. J., Rodríguez-Monje, M. T., Gallardo-Alonso, F., Fernández-Girón, M., Pérez-López, M., \& Chicharro-Romero, J. (2007). Validación de un instrumento para la detección de trastornos de control de impulsos y adicciones: el MULTICAGE CAD-4 [Validation of an instrument for the detection of impulse control disorders and addictions: the MULTICAGE CAD-4]. Trastornos Adictivos, 9, 269-278. https://doi.org/10.1016/S1575-0973(07)75656-8

Pedrero-Pérez, E.J., Ruiz-Sánchez, J.M., Rojo-Mota, G., Llanero-Luque, M., Pedrero-Aguilar, J., MoralesAlonso, S., \& Puerta-García, C. (2018). Tecnologías de la Información y la Comunicación (TIC): uso problemático de Internet, videojuegos, teléfonos móviles, mensajería instantánea y redes sociales mediante el MULTICAGE-TIC. Adicciones, 30(1), 19-32. https://doi.org/10.20882/adicciones.806

Peng, C.-T., Wu, T.-Y., Chen, Y., \& Atkin, D.J. (2019). Comparing and modeling via social media: the social influences of fitspiration on male instagram users' work out intention. Computers in Human Behavior, 99, 156-167. https://doi.org/10.1016/j.chb.2019.05.011

Peris, M., Barrera, U., Schoeps, K., \& Montoya, I. (2020). Psychological risk factors that predict social networking and Internet addiction in adolescents. International Journal of Environmental Research and Public Health, 17(12), e4598. https://doi.org/10.3390/ijerph17124598

Peris, M., Maganto, C., \& Garaigordobil, M., (2018). Scale of risk of addiction to social networks and Internet for adolescents: reliability and validity (ERA-RSI). Revista de Psicología Clinica con Niños y Adolescentes, 5(2), 30-36. https://doi.org/10.21134/rpcna.2018.05.2.4

Real Decreto 463/2020, de 14 de marzo, por el que se declara el estado de alarma para la gestión de la situación de crisis sanitaria ocasionada por el COVID-19 [Royal Decree 463/2020, of March 14, declaring the state of alarm for the management of the health crisis situation caused by COVID-19]. Boletín Oficial del Estado, 67, p. 1-15. https://bit.ly/2JbQcDU 
Rosales, F. L., \& Jasso Medrano, J. L. (2019). Interacción entre el uso y la adicción a las redes sociales y teléfonos móviles entre estudiantes universitarios [Interaction between use and addiction to social networks and mobile phones among university students]. Revista de Investigación en Tecnologías de la Información, 7(14), 76-88. https://doi.org/10.36825/RITI.07.14.007

Ruiz-Palmero, J., Sánchez-Rivas, E., Gómez-García, M., \& Sánchez Vega, E. (2019). Future teachers' smartphone uses and dependence. Education Sciences, 9(3), e194. https://doi.org/10.3390/educsci9030194

Ruiz-Palmero, J., Sánchez-Rodríguez, J., \& Trujillo-Torres, J. M. (2016). Utilización de Internet y dependencia a teléfonos móviles en adolescentes [Internet use and dependence on mobile phones in adolescents]. Revista Latinoamericana de Ciencias Sociales, Niñez y Juventud, 14(2), 1357-1369.

Saikia, A. M., Das, J., Barman, P., \& Bharali, M. D. (2019). Internet addiction and its relationships with depression, anxiety, and stress in urban adolescents of Kamrup District, Assam. Journal of Family \& Community Medicine, 26(2), 108-112. https://doi.org/10.4103/jfcm.JFCM_93_18

Sánchez-Rivas, E., Ruiz-Palmero, J., \& Sánchez-Rodríguez, J. (2017). Videojuegos frente a fichas impresas en la intervención didáctica con alumnado con necesidades educativas especiales [Videogames versus printed cards in the didactic intervention with students with special educational needs]. Educar, 53(1), 29-48. https://doi.org/10.5565/rev/educar.844

Siste, K., Hanafi, E., Sen, L. T., Christian, H., Adrian, Siswidiani, L. P., Prabowo, A., Julivia, B., \& Suwartono, C. (2020). The impact of physical distancing and associated factors towards Internet addiction among adults in Indonesia during COVID-19 pandemic: A nationwide web-based study. Frontiers in Psychiatry, 11, 924. https://doi.org/10.3389/fpsyt.2020.580977

Spanish Association of Video Games (2019). La industria del videojuego en España [The video game industry in Spain]. Anuario 2019. AEVI. http://www.aevi.org.es/web/wp-content/uploads/2020/04/AEVIANUARIO-2019.pdf

Spanish Institute of Statistics (2020). Encuesta sobre Equipamiento y Uso de Tecnologías de Información y Comunicación en los Hogares [Survey on Equipment and Use of Information and Communication Technologies in Homes]. Año 2020. https://bit.ly/2HLvPwn

Tsitsika, A., Tzavela, E., Mavromati, F., \& EU NET ADB Consortium. (2013). Investigación sobre conductas adictivas a Internet entre los adolescentes europeos [Research on addictive Internet behaviors among European adolescents]. http://www.injuve.es/sites/default/files/2013/03/publicaciones/Final ResearchInternet-ES.pdf

Viñals Blanco, A., Abad Galzacorta, M., \& Aguilar Gutiérrez, E. (2014). Jóvenes conectados: Una aproximación al ocio digital de los jóvenes españoles [Young people connected: An approach to digital leisure for young Spanish people]. Communication Papers -Media Literacy \& Gender Studies-, 3(4), 52-68.

World Health Organization (Ed.). (2019). Sharpening the focus on gaming disorder. Bull World Health Organ, 97(6), 382-383. https://doi.org/10.2471/BLT.19.020619

Correspondence: Ernesto Colomo Magaña, Department of Theory and History of Education, University of Malaga (UMA), Spain. E-mail: ecolomo@uma.es 